\title{
Habitat selection of the coral-dwelling spinyhead blenny, Acanthemblemaria spinosa, at Curaçao, Dutch Caribbean
}

\author{
Thijs Böhm ${ }^{1}$ • Bert W. Hoeksema ${ }^{1,2}$
}

Received: 5 May 2016 /Revised: 24 June 2016 / Accepted: 28 June 2016 / Published online: 15 July 2016

(C) The Author(s) 2016. This article is published with open access at Springerlink.com

\begin{abstract}
The distribution, abundance, and habitat preferences of the spinyhead blenny, Acanthemblemaria spinosa (Perciformes, Blennioidei, Chaenopsidae), were studied on coral reefs along the leeward side of Curaçao, southern Caribbean. The blennies inhabited small holes inside coral, which predominantly consisted of calcareous tubes constructed by coralassociated serpulid worms of the species Spirobranchus giganteus. About $50 \%$ of the fish inhabited holes in dead coral, and the rest had their holes in live corals of eight species. The fishes showed a clustered distribution pattern and their abundance was higher at shallow depths (5 and $10 \mathrm{~m}$ ) than at $15 \mathrm{~m}$. Although males generally had a larger body size than females and needed larger holes for shelter and guarding eggs, no sexual dominance in hole selection was found. The position of the holes varied in elevation height above the reef floor, which showed a positive correlation with fish size.
\end{abstract}

Keywords Chaenopsidae $\cdot$ Cryptobenthic reef fish $\cdot$ Serpulid worm tubes $\cdot$ Substrate preference

Communicated by R. Vonk

Electronic supplementary material The online version of this article (doi:10.1007/s12526-016-0543-9) contains supplementary material, which is available to authorized users.

Bert W. Hoeksema

bert.hoeksema@naturalis.nl

1 Naturalis Biodiversity Center, P.O. Box 9517, 2300

RA Leiden, The Netherlands

2 Institute of Biology Leiden, Leiden University, P.O. Box 9505, 2300 RA Leiden, The Netherlands

\section{Introduction}

Cryptobenthic fishes are usually the most diverse and abundant component of reef fish fauna, but they are easily overlooked because of their small sizes and hidden lifestyles (Munday and Jones 1998; Ahmadia et al. 2012a). Their high abundance suggests that they play an important role in the food webs on coral reefs (Wilson 2001; Depczunski and Bellwood 2003). Distribution patterns of such small reef fishes depend on various environmental factors, such as the availability of food and shelter, and depth preferences (Williams 1991; Zikova et al. 2011; Ahmadia et al. 2012a, b; Dalben and Floeter 2012; Harborne et al. 2012; Goatley et al. 2016; Tornabene et al. 2016).

Chaenopsid blennies are small-bodied reef fish that reside in shelter holes, usually cavities created by invertebrates that either deposit a calcium carbonate structure on the coral surface or excavate a pit in the coral matrix (Clarke and Tyler 2003). The genus Acanthemblemaria (Chaenopsidae) is represented by 11 known species in the western Atlantic Ocean (Williams 2002; Bailly 2015). Within this genus, the reefdwelling spinyhead blenny (A. spinosa Metzelaar, 1919) is the most widespread and common species in the Caribbean, from the Bahamas to Curaçao (Smith-Vaniz and Palacio 1974). Its demersal eggs are laid deep inside the male's shelter hole, which are guarded by the male until they hatch into planktonic larvae (Clarke and Tyler 2003). The availability of such holes is a limiting resource for blenny abundance and, therefore, larger blennies dominate smaller ones for access to such holes as long as they can fit inside, which is relevant in both intraspecific and interspecific competition for space (Greenfield and Greenfield 1982; Lindquist 1985; Buchheim and Hixon 1992; Patzner 1999; Wilson et al. 2013).

Spinyhead blennies primarily feed on planktonic calanoid copepods by darting out of their holes (Clarke 1999). In this way, they depend much on food supply through the ambient 
water flow (Clarke et al. 2005, 2009; Finelli et al. 2009). The holes can be used to ambush prey since the planktonic copepods are known to show escape reactions during the approach of A. spinosa individuals (Waggett and Buskey 2007). Previous studies have shown that these copepods are denser at $1 \mathrm{~m}$ above the reef surface than at $0.2 \mathrm{~m}$ (Clarke 1999). Consequently, spinyheads in high locations eat more, grow faster, and have a higher fecundity compared to those at low locations (Clarke 1992).

To satisfy the energy requirements of A. spinosa, the availability of calanoid and cyclopoid copepods should be high (Clarke 1999). Another factor influencing its distribution is the availability of shelter holes (Wilson et al. 2013). Since these fish depend on excavating invertebrates and tube builders to create shelter holes, the distribution and abundance of these invertebrates will influence A. spinosa distribution patterns as well (Luckhurst and Luckhurst 1978).

Deep, solid tubes are preferred by females for the deposition of their eggs, such as limestone tubes deposited by Christmas tree worms, Spirobranchus giganteus (Pallas, 1766), which are very common in the Caribbean and can be found in association with a large range of host corals (Hunte et al. 1990; Hoeksema et al. 2015; Hoeksema and Ten Hove 2016). Therefore, presumably, host coral identity, various shelter-hole properties, depth, and substrate types determine the large-scale distribution of spinyhead blennies, which, on the other hand, may also display small-scale distribution patterns because host coral colonies vary greatly in shape. Stony corals can be microhabitat to a large variety of other animals, including fish, which use their host for shelter, substrate, or food (Stella et al. 2011; Ahmadia et al. 2012b; Hoeksema and Farenzena 2012; Hoeksema et al. 2012, 2013a, b; Coni et al. 2013; Gittenberger and Hoeksema 2013; Tornabene et al. 2013; Van der Meij and Hoeksema 2013; Bos and Hoeksema 2015; Head et al. 2015; Montano et al. 2015; Van der Meij et al. 2015; Goatley et al. 2016; references herein).

In the present study, large- and small-scale distribution is determined as the distribution over coral heads and the distribution within coral heads, respectively. Cheanopsid blennies in particular are suitable for the study of small-scale distribution as they occupy shelter holes in the reef, and thereby occupy a permanent point in space (Greenfield and Greenfield 1982; Clarke 1994). Both male and female spinyhead blennies are expected to be found in such a manner that predation is minimized and food availability is maximized (Clarke and Tyler 2003). In addition, body size in relation to shelter-hole size and distance to the nearest neighbor may influence the small-scale distribution of A. spinosa. Since males constitute the nestguarding gender, they have to dispose suitable shelter holes that attract females for egg deposition. For these reasons it is hypothesized that the sex of the nearest neighbour, shelter-hole size, and location of the shelter hole may result in differentiation in smallscale distribution among male and female spinyhead blennies.
The assessment of distribution and habitat preferences of spinyhead blennies in the present study provides information on both large- and small-scale characteristics determining their distribution, which will contribute to a better understanding of the role of cryptobenthic fish on coral reefs.

\section{Materials and methods}

\section{Study area}

This study consists of two parts: 1. A large-scale survey in which the distribution patterns and habitat preferences of Acanthemblemaria spinosa are investigated on reefs at the leeward side of Curaçao; 2. Small-scale monitoring in which the distribution patterns of A. spinosa individuals are documented within four coral colonies, which were selected for their high occupancy of blennies.

Curaçao is situated in the southern Caribbean, off the north coast of Venezuela. It is ca. $60 \mathrm{~km}$ long and it has a total land surface area of $444 \mathrm{~km}^{2}$. The climate on Curaçao can be described as semi-arid, and seawater temperature around the island varies around $27^{\circ} \mathrm{C}$. The island is surrounded by fringing reefs and is known for its steep drop-offs, which are generally close to the shoreline (Bak 1975; Van Duyl 1985).

Visual census was conducted along the southern leeward coast of the island at four different locations, which were more or less evenly distributed along the coastline: (1) Playa Kalki $\left(12^{\circ} 22^{\prime} 29.6^{\prime \prime} \mathrm{N} 69^{\circ} 09^{\prime} 28.1^{\prime \prime} \mathrm{W}\right),(2)$ Daaibooi $\left(12^{\circ} 12^{\prime} 43.2^{\prime \prime} \mathrm{N}\right.$ $\left.69^{\circ} 05^{\prime} 05.7^{\prime \prime} \mathrm{W}\right)$, (3) Aqualectra $\left(12^{\circ} 06^{\prime} 33.3^{\prime \prime} \mathrm{N} 68^{\circ} 57^{\prime} 15.3^{\prime \prime}\right.$ W), and (4) Director's Bay $\left(12^{\circ} 03^{\prime} 57.5^{\prime \prime} \mathrm{N} 68^{\circ} 51^{\prime} 36.0^{\prime \prime} \mathrm{W}\right)$ (Fig. 1). For detailed information, see Van Duyl (1985). At each site, census was taken for belt quadrats of $20 \times 1 \mathrm{~m}^{2}$ by

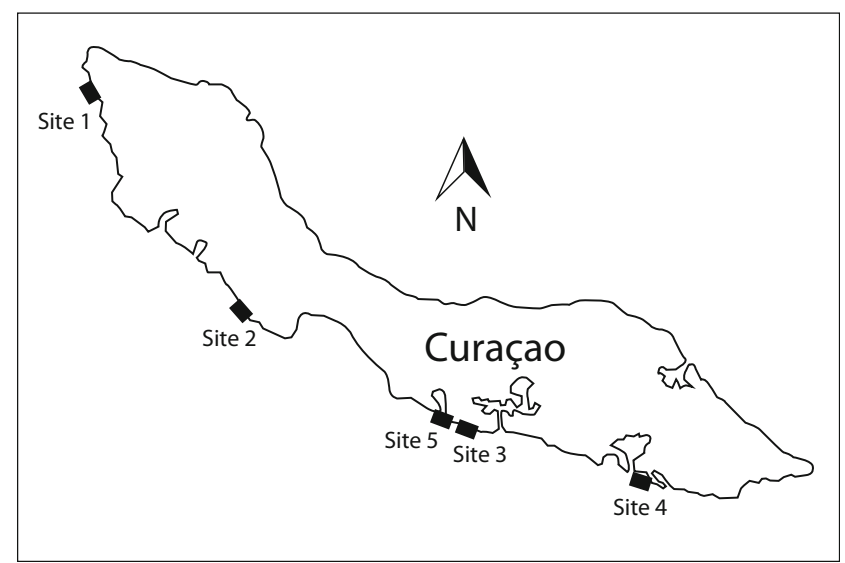

Fig. 1 Map showing five research locations at the leeward side of Curaçao. Site 1 = Playa Kalki, Site 2 = Daaibooi, Site 3 = Water factory (Aqualectra), Site $4=$ Director's Bay, Site $5=$ Piscadera Bay $($ CARMABI Research Station) 

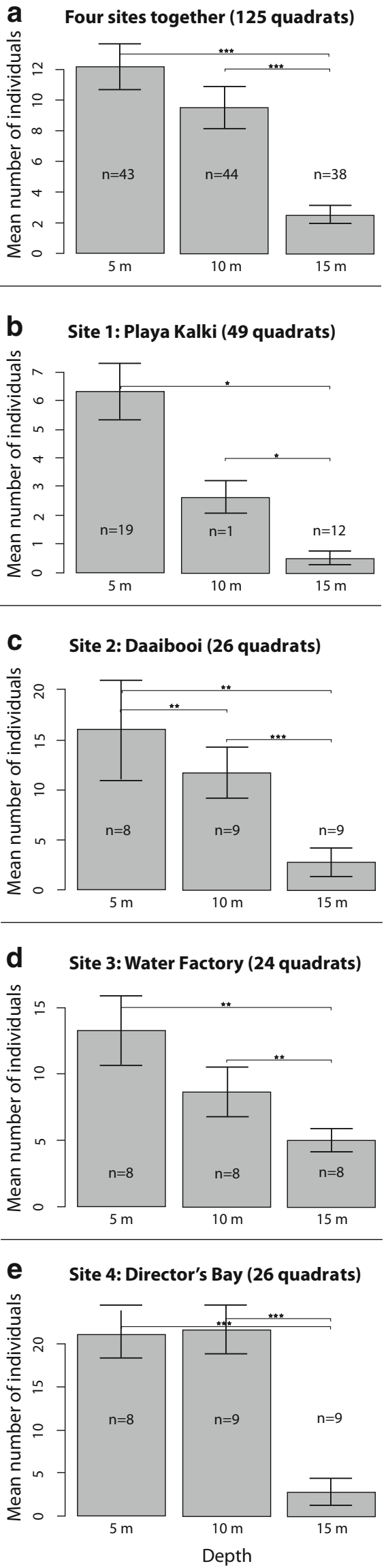

4 Fig. 2 Mean number ( \pm s.d.) of Acanthemblemaria spinosa individuals per $20 \mathrm{~m}^{2}$ quadratat per depth $(5,10$, and $15 \mathrm{~m})$ at reef sites indicated in Fig. 1. a All four sites together. b Site $1=$ Playa Kalki. c Site $2=$ Playa Daabooi. d Site 3 = Water factory. e Site $4=$ Director's Bay. Significant differences between depths: $* * * p<0.001 ; * * p<0.01 ; * p<0.05$

swimming along a $20 \mathrm{~m}$ long measuring tape (transect line) at 5,10 , and $15 \mathrm{~m}$ depth.

Site 1 is situated at the western end of the south side of the island where the bottom is mostly sandy. The slope of the reef was very moderate, and rugosity of the reef was much higher compared to the other locations. Transects at all three depths could be deployed on a gently declining slope.

Site 2 is located further east and has a narrow beach flanked by steep coastal cliffs. The drop-off at this location starts approximately $30 \mathrm{~m}$ from the shore at approximately $10 \mathrm{~m}$ depth. Therefore, transects at $5 \mathrm{~m}$ were set out close to the coastal cliff due to the infrequent occurrence of coral on the sandy bottom.

Site 3 is situated west of Willemstad behind a water/power plant called Aqualectra. At this location, the reef is characterized by a rocky bottom and a moderately declining slope. Transects at $5 \mathrm{~m}$ depth were deployed on the reef flat, whereas the transects at 10 and $15 \mathrm{~m}$ depth were deployed on the slope.

Site 4 is located near the eastern end of the island and is characterized by a nearshore steep reef slope starting at approximately $6 \mathrm{~m}$ depth. At this location the transect lines at both 10 and $15 \mathrm{~m}$ were set out on a steep slope with high live coral cover.

For the second part of this study (small-scale distribution patterns) a fifth site was chosen at Piscadera Bay (Fig. 1), in front of the CARMABI research station. This location was characterized by a shallow reef flat (approximately $4 \mathrm{~m}$ deep), with a high cover of coral heads occupied by tube blennies.

\section{Data collection}

Data collecting was done in February-March 2015, at 5-15 m depth by use of SCUBA. The duration of each dive lasted 60$80 \mathrm{~min}$. Transects were set out by laying a measuring tape on the sea floor. Typically, census could be taken in one dive for three $20 \times 1 \mathrm{~m}^{2}$ quadrats per depth. The number of quadrats (total $n=125$ ) varied between localities due to differences in blenny density (Fig. 2). Blennies encountered during the large-scale study were identified to species level, their host corals were identified and their shelter-hole type was determined. Shelter-hole type was called "worm tube" and otherwise "unknown" if its origin was unknown. For each blenny, a note was made whether it inhabited live or dead coral, and measurements were made of its outer hole diameter, the hole's elevation height (distance from reef floor), the distance to its nearest neighbour (Fig. 3b), and its position along the transect 
line. The shelter-hole diameter was measured by using a calliper. Height above the reef floor, transect position, and distance to nearest neighbour were measured using a measuring tape with accuracies of 5,5 , and $1 \mathrm{~cm}$, respectively. Host corals that could not be identified in situ were photographed and identified afterwards with the help of a field guide (Humann and Deloach 2013). Photographs were taken with an Olympus Tough TG-2 underwater camera in an Olympus PT-053 underwater housing. All findings were noted by use of a pencil and a plastic slate.

For the second part of this study (small-scale at Site 5), four coral heads were selected at approximately $5 \mathrm{~m}$ depth. The size of each coral head was measured, and the number of blennies inhabiting it was counted. Per blenny a coordinate was given and the elevation above the reef floor was measured. In this way, the exact position of each blenny on its host coral head was documented. Afterwards, the hole diameter and hole type were determined in the same manner as described before. The fish $(n=62)$ were individually caught by squirting a harmless anaesthetic (a dilute solution of quinaldine sulfate) into their shelter holes and holding a plastic vial over its opening (Baldwin et al. 1996). All captured fish were brought to the laboratory and stored in vials with a $70 \%$ alcohol solution. Their body length (BL) was measured with a calliper (accuracy $1 \mathrm{~mm}$ ), and their sex was determined under a dissecting microscope by looking for the presence of fingerlike papilla posterior to the anus only known from females.

\section{Data analysis}

Statistical analyses were carried out with R. General linear models (GLM-ANOVA) were conducted to test for differences in fish abundance at various depths and locations. Error structure of the test was quasi-Poisson in order to correct for overdispersion. ANOVA tests were used to test the differences between males and females for shelter-hole diameter, elevation above the reef surface, body size, and sex of the nearest neighbor. A linear model was used to test the correlation between body length and elevation above the reef surface. The Clark-Evans Nearest Neighbor Analysis was used to calculate the distribution pattern of A. spinosa on the reef in order to determine whether their distribution was even, random, or clustered (Clark and Evans 1954).
Fig. 3 Acanthemblemaria spinosa individuals in Piscadera Bay, Curaçao (Site 5). a Single fish (arrow) in a colony of Porites astreoides covered by

Spirobranchus tube worms. b Nearest neigbours in a coral of Pseudodiploria strigosa with tube worms. c Fish inside hole surrounded by dead coral and turf algae. $\mathbf{d}$ Fish in front of its hole in an Orbicella annularis coral. e Individual inhabiting an old serpulid tube inside an Orbicella faveolata coral, which is partly dead. f Blenny dwelling inside a tube of a Spirobranchus worm that was removed 2 days earlier
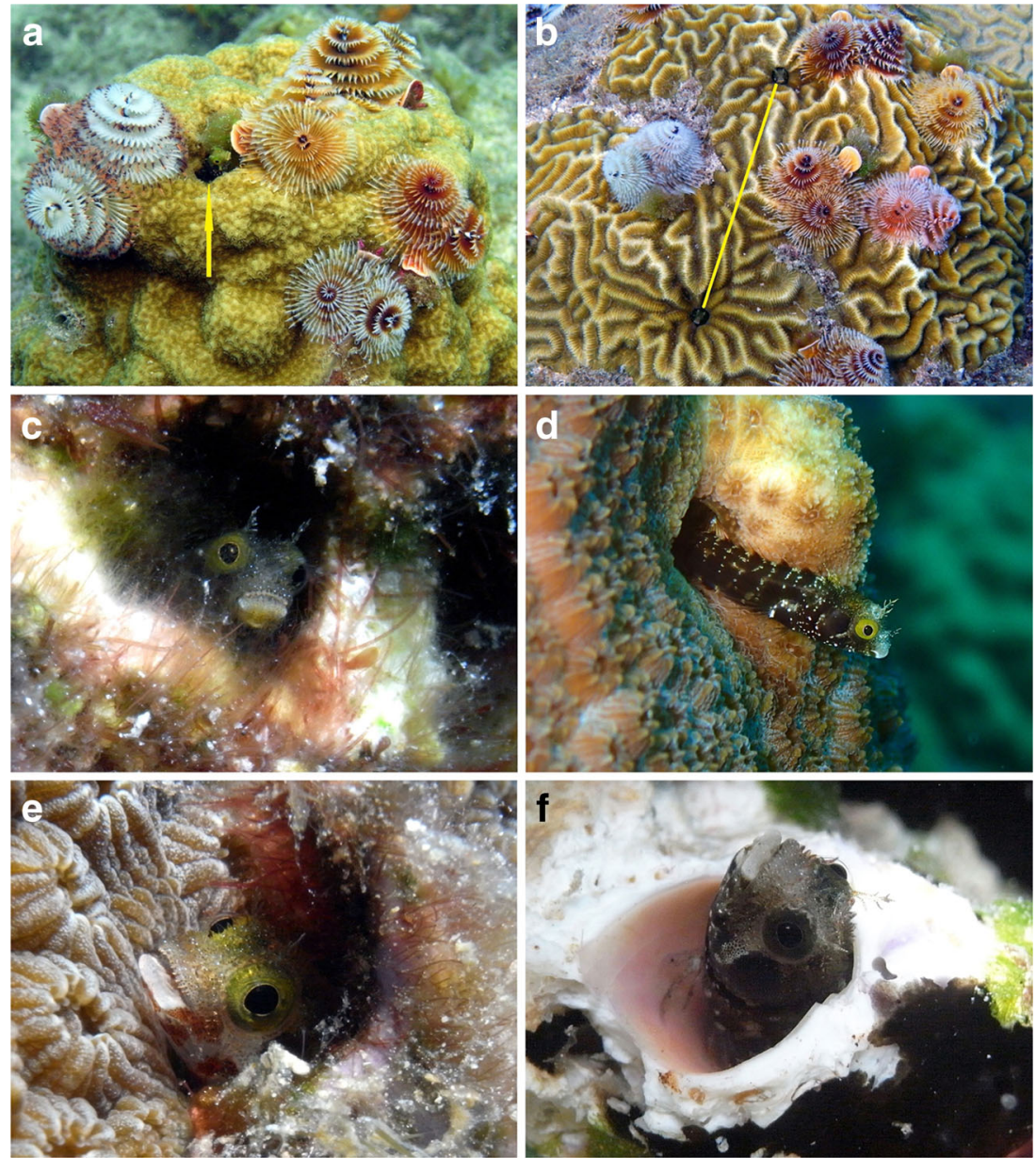


\section{Results}

\section{Large-scale habitat variation}

All Acanthemblemaria spinosa individuals were found inhabiting holes inside hard, stony substrates (Fig. 3). Slightly more than a half (52\%) of the observed A. spinosa individuals $(n=986)$ resided in dead coral (Fig. $3 \mathrm{c})$ and $48 \%$ inhabited live stony coral (Fig. 3a, b, d, e). Occupying dead and live coral did not deviate significantly from a 50/50 distribution $\left(\chi^{2}=0.746, p=0.388\right)$. The live host corals consisted of seven scleractinians and one hydrocoral species: $12 \%$ in Orbicella annularis (Ellis and Solander, 1786), $11 \%$ in Pseudodiploria strigosa (Dana, 1846), $8 \%$ in Orbicella faveolata (Ellis and Solander, 1786), $7 \%$ in Siderastrea siderea (Ellis and Solander, 1786), $6 \%$ in Porites astreoides Lamarck, 1816, 2 \% in Montastraea cavernosa (Linnaeus, 1767), $2 \%$ in Millepora complanata Lamarck, 1816, and $1 \%$ in Agaricia agaricites (Linnaeus, 1758).

Among 852 observed shelter holes, $42 \%$ could be clearly recognized as serpulid tubes and $58 \%$ as holes of other (usually unclear) origin. This difference is significant $\left(\chi^{2}=10.924, p<0.001\right)$. The average shelter-hole diameter was $5.4 \mathrm{~mm}$ within a range of $3-9 \mathrm{~mm}(n=986)$. Average elevation of the holes above the reef floor was $44 \mathrm{~cm}$ within a range of $0-170 \mathrm{~cm}$.

\section{Bathymetrical distribution}

Among the abundances of Acanthemblemaria spinosa measured at 5,10, and $15 \mathrm{~m}$ depths of all sites pooled together, no significant difference in mean number of fish was observed between 5 and $10 \mathrm{~m}(p=0.327)$ (Fig. 2a). The average number of A. spinosa at $5 \mathrm{~m}$ depth was around 12 individuals per 20$\mathrm{m}^{2}$ quadrat, and at $10 \mathrm{~m}$ depth this number was around 10 . The mean density at $15 \mathrm{~m}$ depth was approximately two individuals per quadrat, which is significantly lower than at both other depths $(p<0.0001$; Fig. 2a). Similar results were seen at Sites 2-4 (Fig. 2c-e), whereas at Site 1 the mean number of individuals per quadrat differed significantly among all three depths (Fig. 2b). At Site 4 the density of A. spinosa individuals was slightly higher at $10 \mathrm{~m}$ than at $5 \mathrm{~m}$ (not significant), whereas the quadrat at $15 \mathrm{~m}$ depth shows a significant lower density (Fig. 2e). Sites 1-3 show a gradually decline in blenny density with depth (Fig. 2b-d).

\section{Abundance per locality}

Site 1 showed a mean number of ca. four $A$. spinosa fishes per quadrat, whereas Sites $2-4$ showed mean numbers of approximately $8-15$ (Fig. 4 ), with $p$-values $0.002,<0.001,<0.001$, and 0.002 , respectively (post hoc Tukey test in R). There was no clear gradient along the coastline since Site 1 is the
Mean number per quadrat

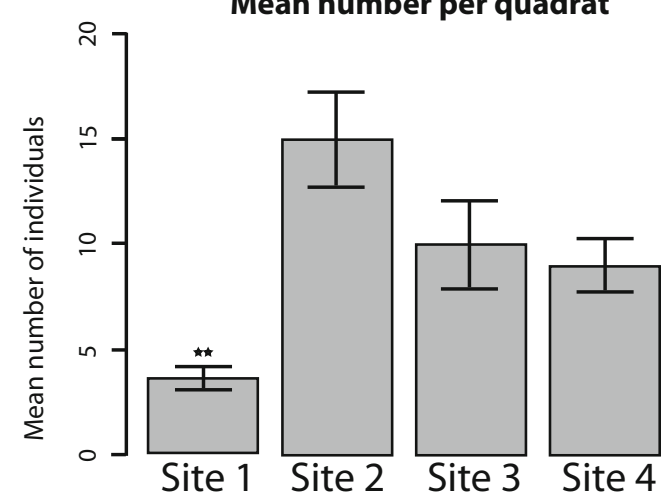

Fig. 4 Mean number ( \pm s.d.) of Acanthemblemaria spinosa individuals per quadrat at four sites along the leeward side of Curaçao. Density at Site 1 is significantly lower than at other sites $(p<0.01)$

northernmost location, whereas the next location, Site 2, had a maximum mean number of almost 15 fish per quadrat.

\section{Nearest neigbours across colonies}

The average nearest-neighbour distance was $32.8 \mathrm{~cm}$. This was calculated from measurements taken from 338 fish counted in a total of 32 quadrats. From this a density of $53.810^{-6}$ fish $\mathrm{cm}^{-2}$ was calculated, which would result in an expected nearest-neighbour distance of $68.8 \mathrm{~cm}$ in a hypothetical randomly distributed population. A relatively low R-value of 0.476 was calculated from the Clarke-Evans nearest-neighbour analysis based on the ratio of observed and expected values. This value is $<1$, suggesting that the distribution pattern of A. spinosa was clustered. The corresponding standard error of the mean distance to nearest neighbour in a randomly distributed population with density rho ( $\sigma \mathrm{rE})$ is 1.9. This means that the probable range of distance to nearest neighbour in a randomly distributed population lies between 66.9 and $70.8 \mathrm{~cm}$. The average distance to nearest neighbour that was measured during this study does not lie within this range and thus it can be assumed with certainty that the distribution pattern of A. spinosa is clustered. The calculated values are summarized in Online Resource 1: Table 1.

\section{Sexual differences in habitat preferences}

The mean diameter of shelter holes was slightly smaller for females $(5.7 \mathrm{~mm})$ than for males $(6.1 \mathrm{~mm})$, but this difference was not significant ( $p=0.068$; Fig. 5a). The difference in mean elevation above the reef bottom is too small to be significant ( $p=0.866$; Fig. $5 b$ ), $19.3 \mathrm{~cm}$ for females and $19.7 \mathrm{~cm}$ for males. The highest recorded individual was a male observed at $46 \mathrm{~cm}$ height. The coral heads used for this part of the study had a maximum elevation above the reef surface ranging from 35 to $65 \mathrm{~cm}$. The body length of the fish ranged between 11 and $20 \mathrm{~mm}$. The mean body length of females 

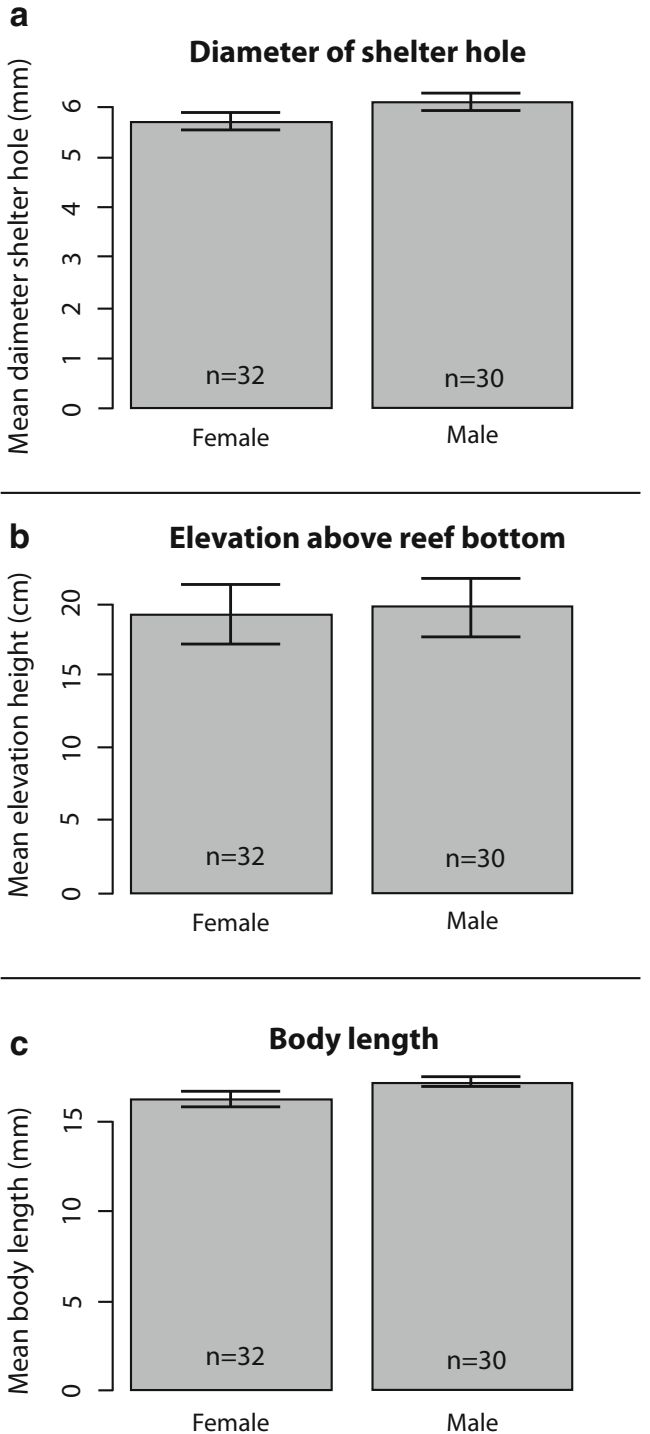

Fig. 5 Comparisons between females and males of Acanthemblemaria spinosa at Piscadera Bay, Curaçao (Site 5) by means ( \pm s.d.) of a diameter of shelter holes $(\mathrm{mm}), \mathbf{b}$ elevation above reef bottom $(\mathrm{cm})$, $\mathbf{c}$ body length $(\mathrm{mm})$

(16.3 mm) was less than for males $(17.2 \mathrm{~mm})$, but this difference was not significant ( $p=0.058$; Fig. $5 c)$.

\section{Correlation between fish length and shelter elevation}

A significant positive correlation was found between body length of the fish and elevation height above the reef bottom $\left(p<0.0001 ; r^{2}=0.2881 ;\right.$ Fig. 6). This result suggests that larger fish occupy holes that are located higher up on the coral heads. However, the $\mathrm{r}^{2}$-value is low, meaning that only a small proportion of the variation in height above the reef is explained by the body length. A log-transformation was performed because there was no homogeneity of variance in the original data.

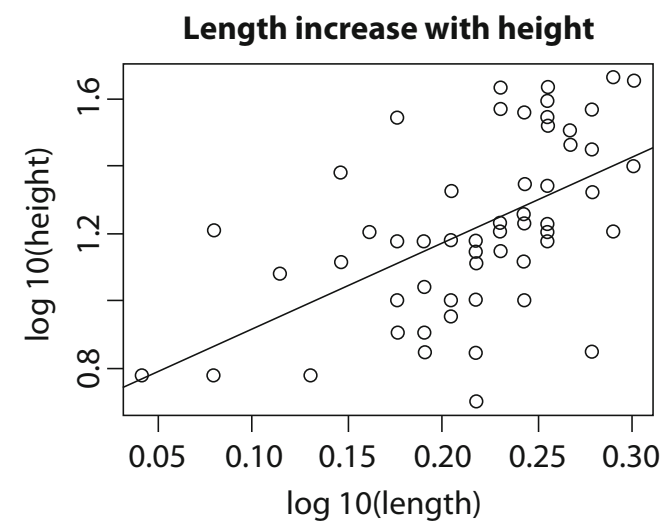

Fig. 6 Correlation between elevation above reef bottom and body length of Acanthemblemaria spinosa specimens in Piscadera Bay, Curaçao (Site 5). Measurements in $\mathrm{cm}$; log scales

In a separate observation, a blenny was found occupying a tube of a Spirobranchus worm that was removed 2 days in advance. The worm tube was situated more than $1.5 \mathrm{~m}$ high on a pillar of a jetty at Site 5 (Fig. 3f).

\section{Nearest neighbours within one coral colony}

The average nearest-neighbour distance at small scale was $8.5 \mathrm{~cm}$. This was calculated from measurements of 62 fish with a density of $24.710^{-2}$ fish $\mathrm{m}^{-2}$. The expected distance to nearest neighbour in a randomly distributed population was calculated to be $10.1 \mathrm{~cm}$. An R-value of 0.841 was calculated with the Clarke-Evans nearest-neighbour analysis. As well as the large-scale distribution, the outcome of the analysis indicates that $A$. spinosa showed a clustered distribution at small scale. The probable distance of nearest neighbour in a randomly distributed population ranges from 9.4 to $10.7 \mathrm{~cm}$ $(\sigma r E=0.67)$. Variables of the analysis are summarized in Online Resource 1: Table 2.

\section{Gender of nearest neighbour}

Gender of the nearest neighbour did not influence the distance to this neighbour. Among all three possible combinations (Female-Female, Male-Female, Male-Male), there was no significant difference in the mean distance to nearest neighbour (ANOVA, $p=0.59$; Fig. 7). Thus, it did not matter whether the nearest neighbour was of the same or the other sex.

\section{Discussion}

Cryptobenthic fish fauna appears to show a general preference for dead coral (Harborne et al. 2012). About half of all spinyhead blennies encountered during this study occurred in dead coral and the other half in live coral. It is unknown whether suitable holes were more or less abundant in dead 


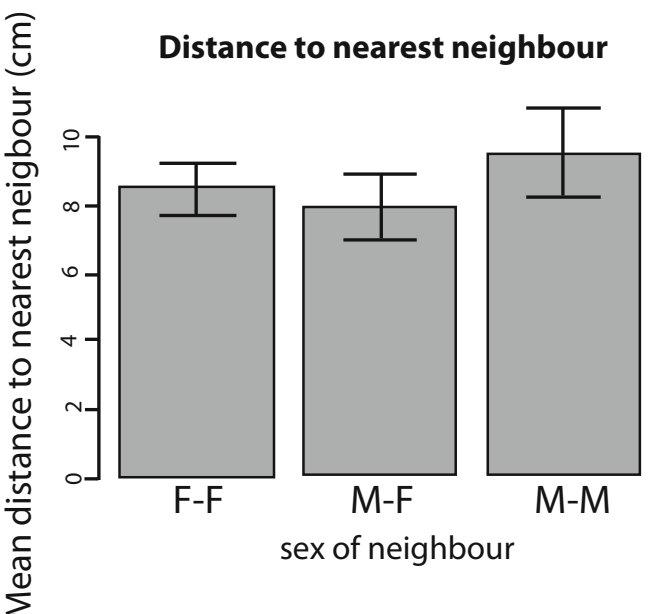

Fig. 7 Mean distance ( \pm s.d.) to nearest neighbor $(\mathrm{cm})$ of Acanthemblemaria spinosa individuals observed in three possible combinations of neighbors at in Piscadera Bay, Curaçao (Site 5). F-F = Female to Female distance, $\mathrm{M}-\mathrm{F}=$ Male to Female distance, $\mathrm{M}-\mathrm{M}=$ Male to Male distance

coral than in live coral because they were difficult to count. Unoccupied holes in dead coral may get overgrown by other organisms, whereas those in live coral may become closed by coral regeneration.

Previous studies in Belize documented spinyhead blennies residing in dead Acropora palmata (Clarke 1989, 1994; Clarke and Tyler 2003). Like elsewhere in the Caribbean, A. palmata abundance in Curaçao has drastically declined in recent decades (Nagelkerken and Nagelkerken 2004; Chamberland et al. 2015), but it is unknown how much of the dead A. palmata has remained. In the absence of dead A. palmata corals, spinyhead blennies have no other option than to select other corals as habitat. Curaçao has undergone much reef degradation over the recent decades and dead coral is abundantly present here (Vermeij 2012). A fifth of A. spinosa's diet consists of benthic, harpacticoid copepods (Clarke 1999), which are more abundant on dead coral than on live coral (Kramer et al. 2014) and this may explain why many spinyhead blennies reside in dead coral.

A. spinosa feeds primarily on planktonic calanoid and cyclopoid copepods, which have denser swarms at $1 \mathrm{~m}$ above the substrate than at $0.2 \mathrm{~m}$ height (Clarke 1999). This agrees with the present finding of a low number of spinyhead blennies in coral species that remain close to the substrate, such as Porites astroides and Agaricia agaricites, and a high number of individuals in corals that grow higher above the substrate (e.g., Orbicella annularis, O. faveolata, and Diploria strigosa). This also explains the high average of elevation above the reef bottom of $44.4 \mathrm{~cm}$ and why A. palmata with its long upward-reaching branches makes an ideal host (Clarke 1996; Clarke and Tyler 2003).

The proportion of $A$. spinosa occupying serpulid tubes is very high, especially considering that this type of hole in dead coral type is difficult to recognize (Fig. 3c). This observation is consistent with results of earlier studies (Luckhurst and Luckhurst 1978; Clarke 1989). This preference can be explained when the size and shape of the worm holes are considered. Spinyhead blennies can have a body length of $2.5 \mathrm{~cm}$ (Smith-Vaniz and Palacio 1974). They should be able to retract completely inside the hole for shelter danger, but also to quickly dart out for feeding (Fig. 3d), for which they need holes that loosely fit to their size (Fig. 3f). Males prefer relatively larger shelter holes than females because they also need space for guarding eggs (Clarke and Tyler 2003). Serpulid tubes are suitable for this goal (Clarke and Tyler 2003) and are abundantly available in Curaçao (Luckhurst and Luckhurst 1978; Fig. 3). An average diameter of $5.4 \mathrm{~mm}$ is indeed slightly larger than the size of the fish, which may be most suitable for optimal protection and manoeuvrability.

Blenny abundance on the reef slope at $15 \mathrm{~m}$ depth is lower than in the shallower reef zones, which may be related to a decreasing gradient in prey abundance from shallow to deep, as seen in planktonic copepods (Yamaguchi et al. 2015). Since there is no significant difference in blenny abundance between 5 and $10 \mathrm{~m}$ depth, food availability may not be restricted at $10 \mathrm{~m}$. Shelter-hole availability may also play an important role in the bathymetrical distribution of blennies, depending on the depth range and density of worms and other invertebrates constructing their shelter holes.

The large-scale clustered distribution pattern of A. spinosa, as indicated by the nearest neighbour analysis, may depend on two factors. 1 . The presence of shelter holes in live and dead coral may be restrictive, but during the present study empty holes were also observed. Since the holes are present in corals that form patches of coral cover over the reef bottom, the available coral surface area with holes is not evenly distributed over the reef, which may explain a clustered distribution pattern of the blennies at large scale. 2 . There may also be a possible tendency in the behaviour of A. spinosa to form aggregations, but this possibility should be tested with the help of experiments in which a variable number of holes with varying sizes is offered to the fish. Perhaps spinyhead blennies are not good long-distance swimmers since experiments showed that some individuals transplanted over distances $>5 \mathrm{~m}$ were not able to return to their own hole, and those released over $>20 \mathrm{~m}$ not at all (Buchheim and Hixon 1992). For mating, the distance between males and females can be restrictive. Therefore, a mixed assemblage can be most advantageous, while stochastically it is also the most obvious pattern.

On a small scale, A. spinosa also shows a clustered distribution pattern. Here, the sample size was much smaller, the fish density about 45 times higher, and the distance to nearest neighbour almost a fourth of the distance at large scale. The small-scale data are based on measurements from four coral colonies that were selected for their high occupancy of 
blennies. The R-value was almost double that of the largescale study. For such a small sample size it is important to know the true density of the population, which requires a complete census (Clark and Evans 1954). Since the density within a selected sample was used and the R-value approached 1, the distribution pattern of A. spinosa at small scale appeared to be slightly clustered, but close to random.

Nevertheless, valuable information on the gender distribution on the coral heads could be obtained since no difference was found in the distribution patterns of males and females. Both sexes show no preference for having a neighbour of the other sex or the same sex. There is also no difference in elevation height between the sexes, as previously found elsewhere (Clarke and Tyler 2003). Hence, gender is not a defining factor in the small-scale distribution pattern of A. spinosa. In the present study shelter holes occupied by males were slightly $(4 \mathrm{~mm})$ wider than those for females, which would make sense because of the egg care of males. However, this difference was not significant, but nearly so, which could have been altered with larger sample sizes.

Body length appears to be positively correlated with elevation height above the reef surface. This supports the hypothesis that shelter holes higher above the reef bottom are preferred and suggests that larger individuals are dominant over smaller ones in the competition for shelter holes. However, the variation in the height above the reef is only partially explained by body length and, therefore, there may be additional factors regulating height distribution of $A$. spinosa, such as the size of the available holes.

All data in this study point to a clustered distribution pattern of A. spinosa on the reef where host coral species, dead coral cover, shelter-hole availability, shelter-hole size, depth, elevation above the reef surface, and body length affect the distribution of the species, apparently independent of gender.

Acknowledgments The field research of the first author was made possible through the much appreciated financial support from the Jan Joost ter Pelkwijk Fund (Naturalis Biodiversity Center) and the Alida M. Buitendijk Fund (Naturalis Biodiversity Center). We are grateful to Gerrit Potkamp and Dasha Wels (University of Amsterdam) for their collaboration. We thank Dr. Mark J.A. Vermeij and other staff of the CARMABI Research Station for their great support at Curaçao. Drs. Raymond D. Clarke (Sarah Lawrence College, Bronxville) and Dr. Ron I. Eytan (Texas A\&M University at Galveston) gave helpful advice on the fish gender identification. We also would like to thank Prof. Dr. A.M. de Roos (University of Amsterdam) for providing helpful tips and feedback during this MSc study. Finally, we thank Dr. Carole C. Baldwin (Smithsonian Institution) and one anonymous reviewer for their constructive comments on the ms.

Open Access This article is distributed under the terms of the Creative Commons Attribution 4.0 International License (http:// creativecommons.org/licenses/by/4.0/), which permits unrestricted use, distribution, and reproduction in any medium, provided you give appropriate credit to the original author(s) and the source, provide a link to the Creative Commons license, and indicate if changes were made.

\section{References}

Ahmadia GN, Sheard LJ, Pezold FL, Smith DJ (2012a) Cryptobenthic fish assemblages across the coral reef-seagrass continuum in SE Sulawesi, Indonesia. Aquat Biol 16:125-135. doi:10.3354/ab00440

Ahmadia GN, Pezold FL, Smith DJ (2012b) Cryptobenthic fish biodiversity and microhabitat use in healthy and degraded coral reefs in SE Sulawesi, Indonesia. Mar Biodivers 42:433-442. doi:10.1007 /s12526-012-0118-3

Bailly N (2015) Acanthemblemaria Metzelaar, 1919. In: Froese R, Pauly D (eds) FishBase. Accessed through: World Register of Marine Species at http://www.marinespecies.org/aphia.php? $\mathrm{p}=$ taxdetails\&id $=254882$ on $2016-06-25$

Bak RPM (1975) Ecological aspects of the distribution of reef corals in the Netherlands Antilles. Bijdr Dierk 45:181-190

Baldwin CC, Collette BB, Parenti LR, Smith DG and Springer VG (1996) Collecting fishes. In: Lang MA, Baldwin CC (eds.) The diving for science - methods and techniques of underwater research. Proceedings of the American Academy of Underwater Sciences (Sixteenth annual Scientific Diving Symposium)

Bos AR, Hoeksema BW (2015) Cryptobenthic fishes and co-inhabiting shrimps associated with the mushroom coral Heliofungia actiniformis (Fungiidae) in the Davao Gulf, Philippines. Environ Biol Fish 98:1479-1489. doi:10.1007/s10641-014-0374-0

Buchheim JR, Hixon MA (1992) Competition for shelter holes in the coral-reef fish Acanthemblemaria spinosa Metzelaar. J Exp Mar Biol Ecol 164:45-54. doi:10.1016/0022-0981(92)90135-W

Chamberland VF, Vermeij MJ, Brittsan M, Carl M, Schick M, Snowden S, Petersen D (2015) Restoration of critically endangered elkhorn coral (Acropora palmata) populations using larvae reared from wild-caught gametes. Global Ecol Conserv 4:526-537. doi:10.1016/j.gecco.2015.10.005

Clark PJ, Evans FC (1954) Distance to nearest neighbour as a measure of spatial relationships in populations. Ecology 4:445-453

Clarke RD (1989) Population fluctuation, competition and microhabitat distribution of two species of tube blennies, Acanthemblemaria (Teleostei: Chaenopsidae). Bull Mar Sci 44:1174-1185

Clarke RD (1992) Effects of microhabitat and metabolic rate on food intake, growth and fecundity of two competing coral reef fishes. Coral Reefs 11:199-205. doi:10.1007/BF00301994

Clarke RD (1994) Habitat partitioning by chaenopsid blennies in Belize and the Virgin Islands. Copeia 2:398-405. doi:10.2307/1446987

Clarke RD (1996) Population shifts in two competing fish species on a degrading coral reef. Mar Ecol Prog Ser 137:51-58. doi:10.3354 /meps 137051

Clarke RD (1999) Diets and metabolic rates of four Caribbean tube blennies, genus Acanthemblemaria (Teleostei: Chaenopsidae). Bull Mar Sci 65:185-199

Clarke RD, Tyler JC (2003) Differential space utilization by male and female spinyhead blennies, Acanthemblemaria spinosa (Teleostei: Ceanopsidae). Copeia 2:241-247. doi:10.1643/0045-8511(2003 )003[0241:DSUBMA]2.0.CO;2

Clarke RD, Buskey EJ, Marsden KC (2005) Effects of water motion and prey behavior on zooplankton capture by two coral reef fishes. Mar Biol 146:1145-1155. doi:10.1007/s00227-004-1528-y

Clarke RD, Finelli CM, Marsden KC (2009) Water flow controls distribution and feeding behavior of two co-occurring coral reef fishes: II. Laboratory experiments. Coral Reefs 28:475-488. doi:10.1007 /s00338-009-0479-7 
Coni EOC, Ferreira CM, Moura RL, Meirelles PM, Kaufman L, FranciniFilho RB (2013) An evaluation of the use of branching fire-corals (Millepora spp.) as refuge by reef fish in the Abrolhos Bank, eastern Brazil. Environ Biol Fish 96:45-55. doi:10.1007/s10641-012-0021-6

Dalben A, Floeter SR (2012) Cryptobenthic reef fishes: depth distribution and correlations with habitat complexity and sea urchins. J Fish Biol 80:852-865. doi:10.1111/j.1095-8649.2012.03231.x

Depczunski M, Bellwood DR (2003) The role of cryptobenthic reef fishes in coral reef trophodynamics. Mar Ecol Prog Ser 256:183-191. doi:10.3354/meps 256183

Finelli CM, Clarke RD, Robinson HE, Buskey EJ (2009) Water flow controls distribution and feeding behavior of two co-occurring coral reef fishes: I. Field measurements. Coral Reefs 28:461-473. doi:10.1007/s00338-009-0481-0

Gittenberger A, Hoeksema BW (2013) Habitat preferences of coralassociated wentletrap snails (Gastropoda: Epitoniidae). Contrib Zool 82:1-25

Goatley CHR, González-Cabello A, Bellwood DR (2016) Reef-scale partitioning of cryptobenthic fish assemblages across the Great Barrier Reef, Australia. Mar Ecol Prog Ser 544:271-280. doi:10.3354/meps11614

Greenfield DW, Greenfield TA (1982) Habitat and resource partitioning between two species of Acanthemblemaria (Pisces: Chaenopsidae), with comments on the chaos hypothesis. Smithson Contrib Mar Sci 12:499-507

Harborne AR, Jelks HL, Smith-Vaniz WF, Rocha LA (2012) Abiotic and biotic controls of cryptobenthic fish assemblages across a Caribbean seascape. Coral Reefs 31:977-990. doi:10.1007/s00338-012-0938-4

Head CE, Bonsall MB, Koldewey H, Pratchett MS, Speight M, Rogers AD (2015) High prevalence of obligate coral-dwelling decapods on dead corals in the Chagos Archipelago, central Indian Ocean. Coral Reefs 34:905-915. doi:10.1007/s00338-015-1307-x

Hoeksema BW, Farenzena ZT (2012) Tissue loss in corals infested by acoelomorph flatworms (Waminoa sp.). Coral Reefs 31:869. doi:10.1007/s00338-012-0919-7

Hoeksema BW, ten Hove HA (2016) The invasive sun coral Tubastraea coccinea hosting a native Christmas tree worm at Curaçao, Dutch Caribbean. Mar Biodivers. doi:10.1007/s12526-016-0472-7

Hoeksema BW, van der Meij SET, Fransen CHJM (2012) The mushroom coral as a habitat. J Mar Biol Assoc UK 92:647-663. doi:10.1017 /S0025315411001445

Hoeksema BW, Scott C, True JD (2013a) Dietary shift in corallivorous Drupella snails following a major bleaching event at Koh Tao, Gulf of Thailand. Coral Reefs 32:423-428. doi:10.1007 /s00338-012-1005-x

Hoeksema BW, Waheed Z, Alamaru A (2013b) Out of sight: aggregations of epizoic comb jellies underneath mushroom corals. Coral Reefs 32:1065. doi:10.1007/s00338-013-1078-1

Hoeksema BW, Lau YW, ten Hove HA (2015) Octocorals as secondary hosts for Christmas tree worms at Curaçao. Bull Mar Sci 91:489490. doi:10.5343/bms.2015.1049

Humann P, DeLoach N (2013) Reef coral identification, 3rd edn. New World Publications, Jacksonville

Hunte W, Conlin BE, Marsden JR (1990) Habitat selection in the tropical polychaete Spirobranchus giganteus. I. Distribution on corals. Mar Biol 104:87-92. doi:10.1007/BF01313161

Kramer MJ, Bellwood DR, Bellwood O (2014) Benthic crustacea on coral reefs: a quantative survey. Mar Ecol Prog Ser 511:105-116. doi: $10.3354 /$ meps 10953

Lindquist DG (1985) Depth zonation, micro habitat, and morphology of three species of Acanthemblemaria (Pisces: Blennioidea) in the Gulf of California, Mexico. Mar Ecol 6:329-344. doi:10.1111/j.14390485.1985.tb00141.x

Luckhurst BE, Luckhurst K (1978) Diurnal space utilization in coral reef fish communities. Mar Biol 49:325-332. doi:10.1007/BF00455027
Montano S, Seveso D, Galli P, Puce S, Hoeksema BW (2015) Mushroom corals as newly recorded hosts of the hydrozoan symbiont Zanclea sp. Mar Biol Res 11:773-779. doi:10.1080/17451000.2015.1009467

Munday PL, Jones GP (1998) The ecological implications of small body size among coral-reef fishes. Oceanogr Mar Biol Annu Rev 36:373-411

Nagelkerken I, Nagelkerken WP (2004) Loss of coral cover and biodiversity on shallow Acropora and Millepora reefs after 31 years on Curaçao, Netherlands Antilles. Bull Mar Sci 74:213-233

Patzner RA (1999) Habitat utilization and depth distribution of small cryptobenthic fishes (Blenniidae, Gobiesocidae, Gobiidae, Tripterygiidae) in Ibiza (western Mediterranean Sea). Environ Biol Fish 55:207-214. doi:10.1023/A:1007535808710

Smith-Vaniz WF, Palacio FJ (1974) Atlantic fishes of the genus Acanthemblemaria, with description of three new species and comments on Pacific species (Clinidae: Chaenopsinae). Proc Acad Sci Philadelphia 125:197-224

Stella JS, Pratchett MS, Hutchings PA, Jones GP (2011) Coral-associated invertebrates: diversity, ecology importance and vulnerability to disturbance. Oceanogr Mar Biol Annu Rev 49:43-104. doi:10.1201 /b11009-3

Tornabene L, Ahmadia GN, Berumen ML, Smith DJ, Jompa J, Pezold F (2013) Evolution of microhabitat association and morphology in a diverse group of cryptobenthic coral reef fishes (Teleostei: Gobiidae: Eviota). Mol Phylogenet Evol 66:391-400. doi:10.1016/j. ympev.2012.10.014

Tornabene L, van Tassel JL, Robertson DR, Baldwin CC (2016) Repeated invasions into the twilight zone: evolutionary origins of a novel assemblage of fishes from deep Caribbean reefs. Mol Ecol. doi: $10.1111 /$ mec.13704

Van der Meij SET, Hoeksema BW (2013) Distribution of gall crabs inhabiting mushroom corals on Semporna reefs, Malaysia. Mar Biodivers 43:53-59. doi:10.1007/s12526-012-0135-2

Van der Meij SET, Fransen CHJM, Pasman LR, Hoeksema BW (2015) Phylogenetic ecology of gall crabs (Cryptochiridae) as associates of mushroom corals (Fungiidae). Ecol Evol 5:5770-5780. doi:10.1002 /ece3.1808

Van Duyl FC (1985) Atlas of the living reefs of Curaçao and Bonaire (Netherlands Antilles). Foundation for Scientific Research in Surinam and the Netherlands Antilles, Utrecht

Vermeij MJ (2012) The current state of Curacao's coral reefs. CARMABI, Curaçao

Waggett RJ, Buskey EJ (2007) Calanoid copepod escape behavior in response to a visual predator. Mar Biol 150:599-607. doi:10.1007 /s00227-006-0384-3

Williams DMB (1991) Patterns and processes in the distribution of coral reef fishes. In: Sale PF (ed) The ecology of fishes on coral reefs. Academic, San Diego, pp 437-474

Williams JT (2002) Chaenopsidae - Tubeblennies. In: Carpenter KE (ed) The living marine resources of the Western Central Atlantic. Volume 3: Bony fishes part 2 (Opistognathidae to Molidae), sea turtles and marine mammals. FAO Species Identification Guide for Fishery Purposes and American Society of Ichthyologists and Herpetologists Special Publication No. 5: FAO, Rome, pp. 17611767

Wilson S (2001) Multiscale habitat associations of detrivorous blennies (Blenniidae: Salariini). Coral Reefs 20:245-251. doi:10.1007 /s003380100165

Wilson SK, Fisher R, Pratchett MS (2013) Differential use of shelter holes by sympatric species of blennies (Blennidae). Mar Biol 160:24052411. doi:10.1007/s00227-013-2235-3

Yamaguchi A, Matsuno K, Homma T (2015) Spatial changes in the vertical distribution of calanoid copepods down to great depths in the North Pacific. Zool Stud 54:13. doi:10.1186/s40555-014-0091-6

Zikova AV, Britaev TA, Ivanenko VN, Mikheev VN (2011) Planktonic and symbiotic organisms in nutrition of coralobiont fish. J Ichthyol 51:769-775. doi:10.1134/S0032945211060105 